\title{
Research on College English Teaching Application Based on TBI Teaching Model
}

\author{
Xiong Weihua ${ }^{1,2}$ \\ (1. NanChang Institute of Science and Technology, Nanchang, 330108; 2. NanChang Institute of \\ Technology, Nanchang, 330044)
}

\section{Keywords: Thematic Content Teaching Method; English Teaching; Application Research}

\begin{abstract}
In recent years, domestic scholars have done some research on the TBI teaching method. The research results show that the thematic teaching model can stimulate the interest of English learners, effectively improve the use of learners' English skills, and promote the improvement of comprehensive English application ability. Based on the topical content (TBI) pedagogy, this paper compares and analyzes 129 students from two classes of non-English majors . The results show that: (1) The use of TBI in college English teaching effectively stimulates students' interest in learning English;(2) The TBI pedagogy has changed students' way of learning English to a certain extent, and helped them to internalize their knowledge of English, improve their academic performance in English, and use their English language skills.
\end{abstract}

\section{Research Background}

The successful experience of Lambert's "immersive" experimental class in Canada in the 1960s made the CBI concept attract the attention of many foreign scholars. The CBI concept, which is content-based teaching method, is a teaching philosophy that aims to achieve foreign language acquisition through subject or subject content teaching. It is an effective teaching method that combines foreign language and subject content for learning. Many foreign language educators abroad have successively practiced and experimented and achieved many successful examples. The study of thematic teaching models abroad has been more than 50 years and it has proved to be an effective teaching model. In China, the CBI pedagogy was first introduced from the mid-1990s. In recent years, domestic scholars have done some research on the Theme-based Language Instruction. The research results show that the topical teaching model can stimulate the interest of English learners, effectively improve the use of learners' English skills, and promote the improvement of comprehensive English application ability (Deng Fuhu, 2014; Cao Peisheng, 2012; CaiJian, 2002; Wang Shixian , 1994). However, the history of TBI pedagogy in China is still very short and still in its infancy. Its potential advantages need to be further discovered.

At present, with the expansion of international exchanges, more and more people are becoming aware of the importance of proficient in English. In this context, college English intensive reading courses play an important role in cultivating students' comprehensive English application ability. However, there are still many problems in current college English teaching. First of all, most teachers still use the traditional English teaching method. They emphasize the language and ignore the teaching of language content. Second, in the course of teaching, students only passively accept knowledge and lack the interaction between teachers and students. This paper proposes the use of subject-based content teaching in college English intensive reading classes in order to improve this situation.

\section{Research Design}

\section{Research Problems}

This paper is intended to answer the following two research questions: 1) To what extent does subject-based content teaching improve students' interest in learning English?2) To what extent does the thematic content pedagogy improve students' English proficiency and English language proficiency? 


\section{Teaching Practice}

The teaching experiment was conducted in two classes in sophomore year, one of which was an experimental class and the other was a reference class. The experiment was one semester. The study period is March 2017 to June 2017, including 16 teaching weeks. This study collected data through questionnaires, teaching experiments, and classroom observations. For the teacher questionnaires, student questionnaires, post-experimental experimental class questionnaires, the author conducts descriptive statistics on the data, analyzes college English teaching and student learning status, and whether the students' interest in English learning and language use can be improved after the experiment is implemented. At the same time, through the analysis of the classroom observation record table, compare the performance of students in the experimental class and reference class in the English class. According to the experimental design, the students in the experimental class and the reference class will conduct a total of 2 tests to understand their initial interest in English learning and their English application ability after the experiment. The social science statistical software SPSS was used to conduct independent sample T-tests on the scores of the experimental class and the reference class to compare whether the students' performance was improved before and after the experiment was implemented. At the end of the experiment, some students and teachers were randomly selected for in-depth interviews.

\section{Results and Discussion}

\section{The Impact of Thematic Content Teaching Method on Students' Interest in Learning English}

Based on TBI teaching theory, we conducted relevant empirical research. By using questionnaires, pretest and posttest before and after the experiment, and by comparing the statistics of classroom performance and test scores, we found that the TBI teaching method can effectively improve students' interest and ability in English learning.

From the survey point of view, since the experimental class teaching method is always based on the TBI teaching method during the experiment implementation process, the teacher's teaching method can also be seen from the student questionnaire. From the evaluation of students' teaching, we have seen gratifying changes in the number of students who think that "English learning is fun and useless" increases from $31 \%$ to $75.9 \%$. No student thinks learning is useless. After a semester of experiments, the students hope that the teachers adopt a teaching model. Up to $78.2 \%$ of students still regard "English teaching as a vivid and interesting situation" as their first choice, which shows that students like this teaching method. In addition, as a college student who has a higher level of thinking and judgment ability, I still like this method after trying some method. This is also an affirmation of the effectiveness of the method. Students in the experimental class are more interested in learning English and are more involved in their participation.

The application of TBI teaching method in college English teaching has changed the phenomenon that teachers in traditional teaching often struggle with rules, students take notes, perform mechanical exercises, and struggle with problems after school. At the same time, it has also emerged from teachings that are more general, "leaning on forms, ignoring meaning, lack of use" or "concerning formal meaning and ignoring practical application". There are topical situations in which students have a different experience of teaching. The whole process of this experiment gave students sufficient language input and a certain space for experience and thinking, allowing students to naturally understand, remember, and apply language rules in context and corpus, and provide possibilities for the internalization of knowledge. At the same time, this has greatly increased students' interest in learning English language. Students also have expectations for English language classes. The use of the TBI pedagogy has greatly increased the opportunities for students and language contact. It is more in line with the cognitive laws of foreign language learning and the "recent development zone" theory. It helps to develop students' language fluency and students can activate thinking. 


\section{The Impact of Thematic Content Teaching Method on Students' English Learning Achievement and Language Application Ability}

TBI pedagogy can improve students' English learning performance and language proficiency.

The most significant result of this study comes from experimental data. The comparison of the results of pretest and posttest clearly shows that the use of TBI thematic teaching method in college English language teaching effectively improves students' English performance. TBI pedagogy can improve students' English learning performance and language proficiency.

In the experiment, we created thematic situations to stimulate students' interest in learning so that teachers and students can perceive the target project in a lifelike interaction, and guide students to correctly understand and use the target project in a certain context to improve classroom teaching effectiveness and improve students'ability to use language. Through experimental testing, students in the experimental class did not have a clear contrast with reference classes in sentence translation. However, in the writing, the composition of the students in the experimental class was very beautiful, and both the grammatical correctness and the sentence pattern were superior.

In short, after research, the author has confirmed that the topic situation teaching method is feasible in college English teaching. At the same time, it also confirmed the reliability of related theories based on the TBI pedagogy. The topic-based situational approach has a positive impact on students' interest in language learning and is conducive to better student achievement. Before conducting topical situational language teaching, teachers should carefully study teaching materials, study students, follow the teaching principles of the student-centered activity center, create real and full of interesting life situations, stimulate students' desire to learn, and let students be in real and interesting situations. To understand, understand and use language.

\section{Suggestions}

Through the study, it is found that TBI teaching method does have a certain influence on students' English learning. However, how to make the "topical situation teaching" more effective puts forward higher requirements for teachers and students. Therefore, the following aspects need to be strengthened in English teaching:

In teaching, teachers must not only improve the teaching concept but also try to improve the classroom, improve teaching methods, and optimize teaching methods so as to better guide students in internalizing knowledge through observation, comprehension, exploration, and application, and improve their ability to use language. Only under the guidance of correct and advanced concepts can teachers prevent deviations in the design of topics and design teaching themes that will help students develop their abilities.

Strengthen teachers' reading of materials and analysis of students. "Subject situation teaching" is rooted in teachers, teaching materials, and a full understanding and analysis of students. Choose a situation that meets the goals of the teaching. When designing the task, fully consider whether the student has enough space for thinking and training. The provision of language support must take into account the students' existing cognitive level and language skills. Therefore, in teaching design, we must make full presuppositions.

Strengthen the cooperation of teachers within the group and bring together the collective wisdom. The use of TBI teaching method in college English teaching puts forward high requirements on teachers' teaching design and implementation. The creation of effective teaching situations is a process of continuous selection in the corpus, and it is also an effort to create in the design of activities. Therefore, it is necessary to rely on the strength of excellent teachers of the preparation group, teaching and research group, and even the entire region. Through the collective preparation of teachers, seminars and other forms of research to study, peer mutual assistance, expert guidance, collision in the exchange, in practice to accumulate to achieve effective college English teaching. 


\section{Acknowledgement}

Project funding: Project of Teaching Reform in Higher Education Institutions in Jiangxi Province (No. JXJG-16-25-6)

\section{References}

[1] Brinton. D. M. Snow. M. A\&Wesche. M. B. Content-Based Second Language Instruction. [M]. New York: Newbury House. 1989.

[2] Leaver, B. L. \& Stryker, S. B. Content-based Instruction for Foreign Language Classroom [J] . Foreign Language Annals, 1989.

[3] Morioka, A. . Teaching Japanese with Content -based Instruction [D]. Los Andes: University of California 2007

[4] Stoller, F. Projectwork: A Means to Promote Language and Content [A] . In J. C. Richards\&W. A. Renandya (Eds. ) . Methodology in Language Teaching: An Anthology of Current Practice [C] . Cambridge: Cambridge University Press, 2002.

[5]CaiJian, Research of Second Language Acquisition and CBI Teaching Model [ J], Journal of Beijing International Studies University, 2002.

[6]CaiJigang. The Characteristics and Countermeasures of College English Teaching in China during the Transition Period [J] . Foreign Language Teaching and Research, 2007(1):27-32.

[7]Chang Junyue, Dong Hainan. An Empirical Study on the Teaching Content of the Basic Stages of English Majors [J], Foreign Language and Foreign Language Teaching, 2008.

[8]Dai Qingning, Lv Ye. CBI Teaching Ideas and Teaching Models[J]. Foreign Language Teaching, 2004.

[9]Wen Qiufang, Wang Lifei. Questioning the Validity of Foreign Language Learning Strategies[J]. Foreign Languages, 2004 (2).

[10]Wang Shixian, CBI--the Direction of Professional English Reading Teaching [J] . Foreign Languages, 1994.

[11]Yuan Pinghua, Yu Liming. University-based Foreign Language Teaching Model Based on Content [J] . Foreign Language Teaching and Research, 2008.

[12]Yuan Pinghua. Research on Content-Based Foreign Language Teaching Model in Chinese College English Teaching Environment [D]. Shanghai Jiaotong University, 2008. 